Marquette University

e-Publications@Marquette

Spanish Languages and Literatures Research and

Languages, Literatures and Culture Faculty

Publications

Research and Publications

$3-1-2010$

Art Education, Class, and Gender in a Foreign Art Gallery: Nineteenth-Century Cultural Travelers and the Prado Museum in Madrid

Eugenia Afinoguénova

Marquette University, eugenia.afinoguenova@marquette.edu

Accepted version. Nineteenth-Century Contexts, Vol. 32, No. 1 (March 2010), DOI. C 2010 Taylor \& Francis (Routledge). Used with permission. 


\title{
Art Education, Class, and Gender in a Foreign Art Gallery: Nineteenth- Century Cultural Travelers and the Prado Museum in Madrid
}

\author{
Eugenia Afinoguénova \\ Foreign Languages and Literatures Department, Marquette University \\ Milwaukee, WI
}

The second half of the nineteenth century witnessed the birth of a new trend in European middle-class travel: visiting art galleries and producing written accounts of the experience. Although these stories are frequently used to reconstruct the histories of European museums, we might also ask why their authors felt compelled to view art abroad, in the first place, and write about it, in the second. Indeed, for English and American travelers, a visit to the Prado entailed a long side-trip North from their usual Spanish destination, Andalucía. The journey required physical sacrifice and only brought skimpy spiritual rewards. Madrid, a "clean modern town" without "a cathedral or churches of any note," in the words of the British traveler Zouch $\mathrm{H}$. Turton, could offer no distinguishing adventure (44). "There is [...] no glory of tradition here. There are no cathedrals. There are no ruins. [...] There is nothing indigenous in Madrid," complained Turton's compatriot John Hay (67). American journalist Kate Field followed suit in a sarcastic key:

"Madrid is most satisfactory to travelers in a hurry who are morbid on the subject of embracing opportunities. It is an inexpressible comfort to know that you cannot improve your mind. Churches do not lie in wait for you, nor do ruins upbraid you for not sketching them on the spot" (131-32). There was, thus, only one justification for a trip to Madrid: visiting the Museum, "an attraction that makes one quite forget that the surrounding country is somewhat ugly, and that the 
climate is somewhat bad," as Annie Jane Harvey put it (91). In middleclass men and women whose exposure to art was recent and limited, such determination may strike one as unusual.

As scholars know, travelers' stories are normally rooted in the accounts of their predecessors and often reproduce preconceived ideas. ${ }^{1}$ What deserve further attention, however, are the class, gender, and personal positions defended or disputed whenever a lay traveler decides to engage with an art gallery. Recent research on museum-going in different European countries has greatly facilitated this type of inquiry, as it allows one to relate the travelers' impressions and comments to art-educational agendas and cultural policies that were being debated back at home. The present article will trace one of these transnational dialogues, focusing on stories about visits to the Prado written by British and American travelers during the second half of the nineteenth century. Texts written after 1870 will be of particular relevance, since at this time, while the Prado underwent a transformation from a Royal (1819) to a National (1870-72) museum, Britain and the United States were pioneering art education as a form of social engineering.

Contrary to what one might expect, the relation between domestic cultural practices and their reenactments abroad was far from straightforward. As we shall see, while the travelers' interest in museums was triggered by the expansion of art education and the ensuing legitimization of middle class taste, their narratives followed the most elitist trends of travel writing. Thus, although they were drawn to the museums by a bourgeois passion for personal improvement, they used the occasion to present themselves as aristocratic connoisseurs. From this point of view, female travelers appear particularly interesting, as their descriptions counter the tendencies, embedded in bourgeois art education, to expose women only to art that would support their domestic role.

Given the travelers' tendency to use writing for 'selfdifferentiation' at a time when touring foreign lands was becoming a mass pursuit (Buzard 2002: 49), the visitors' self-portraits as knowledgeable and solitary masterpiece-lovers will come as no surprise. Of more interest is how the directors of the Prado used the 
foreigners' accounts to justify their delayed engagement with exhibiting norms that were becoming customary in the bourgeois art museums. Moreover, given the uneven progress of art education across Europe, it is worth examining whether foreign visitors had any influence on local museum-goers. The theoretical and historical underpinnings of nineteenth-century museum travel are traced in Part 1 of this article. Part 2 will examine the Anglo-American travelers' textual constructions of the Prado experience as a vehicle of their class and gender self-legitimization. Part 3 will review the uses of the travelers' accounts in Spain and examine available sources documenting the interaction between foreign and local visitors at the museum.

\section{Museums, from Cosmopolitan to National}

If eighteenth- and early nineteenth-century national art galleries stood out as monuments to Royal or State patronage or as progressive institutions of the public sphere, by the second half of the nineteenth century they had been transformed into attractions at the core of an emerging tourism industry. As such, art museums presented an interesting case: dedicated to showcasing a nation's heritage, they were yet utilized from both within and outside its territory. Such "travelling" sites (to use James Clifford's coinage), validated in terms of how they are perceived by the members of other communities, are particularly difficult to analyze (Clifford 17-46). The reason, as John Urry suggests, lies in the fact that institutions with an international clientele belong to "new hybrid cultures which are largely unremembered within existing institutional representations of the past" (46). Nevertheless, they have an enormous bearing on any nation's sense of self. Scholars studying the impact of tourism on national identity have demonstrated that under any emblematic site lies a "hybrid" foundation where foreign interpretations and domestic uses merge. ${ }^{2}$

In order to understand what the Prado meant for its AngloSaxon visitors and how important their opinions were for Spanish authorities and opinion-makers, one will have to remember that those dedicated men and women who, in their own words, could spend entire days contemplating a picture by Velázquez or Murillo had 
learned about museums some time around the mid-nineteenth century. At that time, the European art world was undergoing a major transformation. Although the timelines and social consequences differed considerably from one country to another, these changes can be summarized as follows: 1) the monopoly over taste was transferred from the aristocracy to an entity defined as the "nation" in terms undergoing continuous expansion; 2) art began to match the territories of nation-states; 3) State patronage expanded, transforming art into a matter of public policy; 4) formal education in aesthetics, art history, and drawing became available and was invested with the double function of ensuring social cohesion and assisting the professional development of the working classes. For women, the paradoxical result of this development was the consolidation of a certain female version of art education, similar to those reserved for the working classes in its tendency to limit women's artistic experience to utilitarian purposes. Although the importance of women's exposure to art was widely recognized, arts were meant to either buttress their aptitude in crafts (especially embroidery) or prepare them to better exercise their domestic duties, such as home decoration and the education of children.

\section{Art Education in Britain}

Before British middle-class men and women began touring foreign art galleries, British policy-makers of the 1830s-1850s had to undertake considerable efforts in promoting domestic museums among commoners (Bennett, 1995). By expanding the circle of museumgoers, their policies also meant that art was now viewed and described for reasons hitherto unknown. During the same period, the social and economic usefulness of art for working classes and for women was recognized. But, although women of diverse social extractions were drawn into art museums alongside working men, early promoters of museum-going did not address female audiences (Bennett 1996: 2-4). It is against this background that I propose to read accounts of the Prado from travelers whose age and origins suggest that they owed their exposure to art to the cultural climate of the day.

Holger Hoock describes the early stage of this evolution in art museums' social role, taking place in early nineteenth-century Britain, 
as a passage from the "virtual representation" of a nation's merit encapsulated in the innate aesthetic refinement of its few selected citizens, to a belief that aesthetic education had to go along with the moral improvement of the working classes. These were viewed, first, as potential and, later on, as actual citizens (259 et passim). An important part of the process was the growing importance of local constituencies for art. While the notion of the "virtual representation" was limited to communicating a nation's refined taste to the equallycultured audiences belonging to other territories of the cosmopolitan "civilization," the post-Napoleonic nationalization of art was mainly concerned with domestic audiences-exclusively male-which it addressed as tax-payers, army recruits, patriots, or citizens (Conlin). At the same time, considerations about the political implications of exposing various social classes to art translated into debates about museum regulations and admissions in both the press and the government (Bennett 1995; Prior 2002: 92-94; Whitehead 2005: 5969). Popular taste and attitude became the subjects of discussions in contexts ranging from political to ethical, and all major European museums began collecting statistical data about their visitors (Bennett 1996: 5-6). At this time, public art museums' exhibits were reorganized along the lines that suggested the chronological development of national "schools," fulfilling a twofold function of configuring national art and displaying it in the ways deemed intelligible for commoners, who were thought to lack an innate capacity to distinguish the beautiful from the mediocre.

According to Peter Mandler, after its 1848 apogee, the partnership between the State and art in Britain, which had been seen as a means of promoting national integration, took a different route that relied more and more on commercial cultural institutions (11520). In the 1850 s-1870s, private artistic foundations adopted fragmented yet pioneering policies which brought art to the social groups whose citizenship status was sometimes still under dispute. In this context, it is important to remember Ruskin's early engagement with art education at a Working Men's College in the middle of the century. It was during the same time when formal art education as part of women's professional preparation was pioneered, also in Britain, thanks to the efforts of E. P. Hughes, director of the Women's Training College at Cambridge, and Emily Davies, founder of the 
Kensington Society in 1866 and of Girton College in 1869. The 1870s was also the decade when the British example of introducing the history, theory, and practice of art into the curricula of postsecondary, grammar, and secondary schools was being imitated on the other side of the Atlantic, first in Boston (1870), and later in other cities (Grant Dexter, 403).

In aesthetics, the democratization of art erased the differences between two notions which previously had served to explain the impact of artistic creation on individual development: those of natural and aesthetic beauty, whose former separation had made possible the idea of self-cultivation and self-improvement (Bildung) through an exposure to art. According to Hans-Georg Gadamer, early-nineteenth century "cultured (gebildete) consciousness" deriving from classical aesthetics had been characterized by the dismissal of the sociallydetermined consensual notion of taste and by overcoming any emotional reaction to art (73). ${ }^{3}$ Yet as Pierre Bourdieu's analysis of "distinction" suggests, the bourgeoisie legitimized the disposition toward art as a marker of class and ushered socially-negotiated taste into the sphere of aesthetics. Similarly, the unification of natural and aesthetic beauty brought emotions back into the debate about art. Hence, it was no longer individual Bildung, but rather a collective production of taste that was supposed to be taking place at British art galleries during the second half of the nineteenth century.

The travelers to the Prado in the second half of the century were likely to have witnessed these transformations. True, they were coming from different regions and backgrounds. Zouch Horace Turton was Vicar of St. Mary's Southtown, Great Yarmouth in Norfolk. Henry Day was a New York lawyer. His compatriot, the Bostonian John Hay, declared himself the supporter of the First Republic of 1873 but seemed to be a regular guest at Madrid's most aristocratic gatherings (14-15). Among women, Matilda Betham Edwards, a farmer's daughter from Sussex, was of the humblest origin, although by the time when she visited Spain she had acquired a reputation of a wellselling writer of fiction (Rees). Marguerite Tollemache, the sister-in law of Lady Mount Temple was, perhaps, of the highest social extraction of all travelers analyzed here (Gregory). Susan Hale, the wife of the Unitarian minister Rev. Edward E. Hale, with whom she co-authored and permission has been granted for this version to appear in e-Publications@Marquette. Taylor \& Francis (Routledge) does not grant permission for this article to be further copied/distributed or hosted elsewhere without the express permission from Taylor \& Francis (Routledge). 
several travel books, belonged to a prominent Boston family. Kate Field, a descendant of a family of actors and playwrights, was a bestselling journalist and lecturer soon-to-become a playwright herself (Scharnhorst). The difference in origins and social extractions did not prevent the travelers from addressing art in remarkably similar ways. They relied on a fixed set of sources (Richard Ford, Henry O'Shea, Sir Stirling Maxwell, and John Ruskin), acknowledged the existence of national "schools" of art, and approached paintings from the positions of morality and reason. Female authors, as we shall see, came to Madrid as well prepared as the male travelers, but their position vis-àvis the exhibits was far more complex.

\section{Art Education in Spain and the Prado Museum}

In Spain, similar changes occurred over a much shorter period of time between 1868 and the 1880s. Although the concept of a "nation" as the depository of sovereignty dated back to the antiNapoleonic resistance in Cádiz in 1812, the return of absolute rule with Ferdinand VII in 1814 and the weak constitutional monarchy of Ferdinand's daughter Isabella II (1833-1868) preserved aristocratic patronage of the arts and suppressed debates about the aesthetic education of citizens until after the bourgeois revolution of 1868 . Only a month after the Revolution, the government issued a new national calling for "the study of the principles of art and Spanish history" to become part of the curriculum in secondary education (Decreto de 25 de octubre de 1868). By the 1880s art theory and history were taught not only in Spain's universities, but also in professional, grammar, and even a few elementary schools. Shortly prior to formal education in art history, practical training in the fundamentals of art began to expand.

Escuelas especiales de Pintura, Escultura y Arquitectura had been catering to the upper classes in Madrid since 1844. In the 1860 s drawing was already being taught for professional preparation of the members of the lower classes at Conservatorio de Artes. In 1871, a school of painting was incorporated into the Conservatorio, transforming it into the Escuela de artes $y$ oficios. Free of charge and directed toward working-class men, the school boasted nine sections dedicated to "plastic and graphic education," which included two hours daily of classes in lineal and geometrical drawing, shapes and 
decorations, perspective, coloring, and composition. One of the sections offered daily two-hour classes of drawing, "applied to common-life uses," to "señoritas," who were reported to "attend with great benefit for themselves" (de los Ríos: 524").

Thus since the early 1870 s Spain seemed to have joined the community of the nations deeming it important to provide art education to their citizens. Unsurprisingly, from 1872 onward the Spanish liberal press continuously referenced projects of comprehensive art education in Britain and other countries (Sempere y Miguel 1872, 1873, Tubino 1873, Cossío 1878, 1886, 1887). Yet after the short-lived First Republic (1873-74) and the restoration of the Borbons in 1874 , only the members of a progressive private institution of secondary education, Institución Libre de Enseñanza, continued these efforts. Needless to say, when dealing with women, the policy shared the deficiencies characteristic of nineteenth-century art education elsewhere. Working class women, who were introduced to art as a step towards acquiring a profession, and upper class women, who were exposed to art as educators of children and as guardians of health and morality in the domestic sphere, were instructed almost exclusively in drawing and in the art of floral still-lives and landscapes; they were not admitted to classes in anatomy or live figure drawing (de Diego).

Nationalized after the 1868 revolution, the Prado mirrored the belated democratization of the arts in Spain but did not stand up to its highest achievements. Opened in 1819 as a Royal Museum or Museo Fernandino, it had epitomized the court's outreach into the public sphere, and its early admission policies reflected the authorities' interest in artists and connoisseurs and their disregard for the working classes. During the first eight years of its existence, the Prado was open to the public on Wednesdays and thereafter on Saturdays as well. One would have had to wait until 1838 to see the museum open on Sundays; But even that decision was motivated more by the need to prevent the public from bothering art students and amateur artists who were copying paintings on display than by any Royal concern for enlightening the masses (Géal 318-319). The fact that the Museum did not care about working-class visitors is reflected in much of the early descriptive literature, both foreign and domestic, whose tone is and permission has been granted for this version to appear in e-Publications@Marquette. Taylor \& Francis (Routledge) does not grant permission for this article to be further copied/distributed or hosted elsewhere without the express permission from Taylor \& Francis (Routledge). 
predominantly elitist. Thus, in 1831, French writer Prosper Merimée praised the authorities for not admitting the general public on Sundays, contrasting his pleasurable experience of the Prado with that of the Louvre (73-75). However, the years prior to the museum's nationalization brought a steady increase in middle-class domestic visitors, who had learned their habits of viewing art at the National Exhibitions that were been celebrated at the former National Museum (a.k.a. de la Trinidad) since 1856. The growing democratization of the visitorship also induced curators to mark the paintings with special plates featuring the artists' names (1856). Prior to that, only a number in the corner would allow literate visitors to identify a painting by its entry in the catalogue.

In 1873, during the First Republic, the education of the public finally appeared on the State's agenda for the museum, although the idea would not be implemented until the 1920s. The authorities did, however, succeed in another task that is usually associated with a museum's reinterpretation as a civilizing space for the masses: the collection of the data on attendance. This was also the time when an entrance fee was instituted for all days except Sundays and holidays. While the data demonstrate impressive growth in general attendance, the number of paying visitors grew the most. And, since the "masses" visited the museum of Sundays, and art-insiders obtained special permission to visit the museum without paying a fee, the disproportionally large numbers of paying visitors arguably pointed to its growing bourgeois base. Representations of the museum in the local press also testify to its increasing importance in the middle-class male imagination as a place of social mingling and sexual contact (Afinoguénova).

Although the museum authorities declared their intention to organize and exhibit the collection according to national schools, the task was only fully implemented in 1927. The awkward fact that the space had originally been designed to house a Museum of Natural History and the lacunae in the collection itself were the most commonly cited reasons why Spain's most prominent museum had remained a collection of masterpieces rather than a comprehensive chronological display of "schools." These debates continued even after 
nationalization, when its capacity to illustrate the history of national schools of art became widely recognized.

The preceding analysis suggests that Anglo-American visitors were drawn into the Prado by what in their home countries was already a norm or a habit: a desire to classify art and define one's own moral position and taste. However, although the progressive educational reforms had already begun to bring middle-class Spaniards to the museums and introduce them to the values of art history, the Prado could offer no such comprehensive experience and did not teach to analyze art those visitors who came unprepared. Different modes of approaching artistic displays coming from foreign and domestic clientele make one wonder to what degree the Prado depended on its international reputation for maintaining its national status.

\section{The Purposes of Museum Travel}

If, by the middle of the nineteenth century, Britain and America had started to promote middle-class museum-going by means of arteducational policies and programs, one could expect to find the fruits of such a democratic approach in the writings of travelers who visited the Prado in the 1860s-1880s. One might also hope to find observations about local museum-goers and support for the arteducational reform taking place in Spain since early 1870s. Yet in reality, as we shall now see, foreign visitors' accounts are marked by two contradictory tendencies. On the one hand, their very idea of touring foreign galleries was directly related to the fact that in their home countries museums had become accessible not only to connoisseurs, but also to amateurs, male and female. On the other hand, their accounts of the Prado read like narratives of escape from the overcrowded museums back home.

In order to understand these stories, one should keep in mind that side-trips to Madrid often defeated the purpose of traveling to Spain-an exotic destination. Thus, the ensuing analysis will refer to books that respond to the diffuse generic definitions of Romantic travel and whose very titles place Spain in contexts that were either orientalizing or picturesque: To the Desert and Back, or, Travels in Spain, the Barbary States, Italy, etc., in 1875-76, Through Spain to 
the Sahara, and so on. Buzard's oft-cited interpretation of the statusdefining nature of cultural travel helps to resolve this apparent contradiction (1993). Arguably, describing one's visit to an art gallery and taking a dangerous trip to a quasi-African nation served the same purpose of countering the growing availability of travel in an age of rapid transport and mass tourism. For women, both experiences were also means to transcend the limits of domesticity, imposed by the bourgeois reorganization of society. As Tollemache puts it, "Spain is probably the only European country which has not been overrun by tourists. Whilst the Picture Galleries of Italy, Germany, and even of St. Petersburg are familiar to most English travelers, the Royal Museum at Madrid, which contains, perhaps, the finest collection of Pictures in the world, is comparatively unknown" (33, capitalization in the original). This type of reconstruction of the Prado allowed visitors to simultaneously promote the Museum as "the shrine of all pilgrims of taste" (Hay, 5) and portray themselves as such pilgrims.

\section{A Museum for Connoisseurs}

Visitors to the Prado, male and female, described themselves as driven by a desire to study art. As Betham Edwards put it, "We had come ostensibly to Madrid to see the works of Velázquez, and we carried out our intention, not glancing at, but really looking into and studying them as we study Homer, or Shakespeare, or Cervantes.[...] The journey from London to Madrid is costly and fatiguing; but I advise any one to make it who is desirous of receiving a good lesson in $\operatorname{art}^{\prime \prime}(46,63)$. Many other travelers remember having spent two or more days, or even their entire visit, in the museum. Harvey remembers: "A day rarely passed that we did not spend some hours there, and yet when we left Madrid we felt that we were only beginning to become acquainted with even our favourites" (94), while Day affirms that "the traveler will not be satisfied to finish a day of sight-seeing without a daily visit to the Museo" (53). Yet inspecting the guest books that every visitor had to sign, I found virtually no repeated names on any successive days, which suggest that the travelers either returned to the museum on a Sunday, a day of open public admission not suitable for the silent study of works of art, or in fact did not come to the museum every day (Libros de visita, Archivo del Museo Nacional del Prado). 
NOT THE PUBLISHED VERSION; this is the author's final, peer-reviewed manuscript. The published version may be accessed by following the link in the citation at the bottom of the page.

Just as the visitors presented themselves as connoisseurs, they construed the Prado as a place fit not merely for enjoyment, but also for the intellectual study of art. Betham Edwards, for example, depicted the museum as a place perfect of contemplation for viewers that are highly intellectual:

All is quiet, and silent, and orderly as in a church; the rooms are unadorned and perfectly lighted; the pictures are never hidden by crowds of copyists; the place is never crowded or noisy; and after contemplating your favourite pictures or picture for a time, you leave the gallery, not tired and blinded by too many impressions, but refreshed and invigorated with a calm intellectual enjoyment that is as good and simple as it is deep and lasting. (80)

Tollemache writes in a similar way: "A sense of intense satisfaction, such as can hardly be defined, spreads itself through every chunk and corner of the mind, as this Gallery is traversed. The eye is not fatigued, the light admitted in the center of the vaulted ceiling is pleasant to the sight, and perfect as regards the pictures" (34). Day, who remembered visiting the Gallery every afternoon, remarks that it is "exceedingly well arranged," "cool in the Summer and warm in the Winter, and every facility is given to artists who wish to copy". In reality, though, the deficiencies of light and the lack of exhibition space were two main problems that the museum faced in the nineteenth century. Therefore, male and female travelers equally flattered the Prado in order to position themselves as art lovers.

\section{Bildung and the Overcoming of Emotions}

While emphasizing their own exquisite taste, these visitors, nevertheless, employ a large number of topoi that evoke their struggle to transcend mere emotion and reach the "calm intellectual enjoyment" that Betham Edwards described. In their descriptions, both the initial, emotional impression and its later intellectual overcoming are equally important. Thus, Alfred Elwes confesses that he was 'struck at once" by Velázquez, Murillo, and Ribera's work, but proceeds to reasoning:

On a close examination his [Velázquez's] colours seem to have been literally thrown upon the canvas, as if he wielded his brush like a sword and slashed at his work, but the effect, when viewed at a little distance, is truly marvelous. There is a Christ crucified, with a partly-clotted hair hanging over the dropped

Nineteenth-Century Contests, Vol. 32, No. 1 (January 2010): pg. 47-63. DOI. This article is @ Taylor \& Francis (Routledge) and permission has been granted for this version to appear in e-Publications@Marquette. Taylor \& Francis (Routledge) does not grant permission for this article to be further copied/distributed or hosted elsewhere without the express permission from Taylor \& Francis (Routledge). 
NOT THE PUBLISHED VERSION; this is the author's final, peer-reviewed manuscript. The published version may be accessed by following the link in the citation at the bottom of the page.

head that makes you shudder, so wonderful is its execution, so terribly like unto death. (66)

The tendency to rationalize emotions is equally characteristic of female travelers. But their defenses of aesthetic judgment against mere emotional enjoyment are of particular interest, as they indicate the authors' desire to protect their right to interpret art in a civicminded and non-sentimental way. Unwilling to confine themselves to domestic and educational aesthetics only, women travelers base their judgments on their knowledge of artistic technique, historical subjects and terminology. Thus, Tollemache, who notes that the impression of the Museum is "deep and lasting", but laments the absence of a written catalogue (for which she intends to substitute by writing her book), insists on the need to overcome the initial emotional perception of Raphael's Visitation: "The first impression of this picture is perhaps not pleasing, but wait awhile, and it will be engraven" (42-43). In a similar vein, Betham Edwards exhibits knowledge of art-critical terminology and a knack for philosophical interpretation:

Thus it happens that when you come away from his pictures, you forget the painter and the painting, and you remember only the subjects, - not elevated subjects, often quite the contrary, but aesthetically conceived by an intellect so unswerving, and touched with a hand so masterly, that they seem to "live, and move, and have their being." [...] His power of painting circumambient air, his knowledge of lineal and aerial perspective, the gradation of tones in light, and shadow, and colour, give an absolute concavity to the flat surface of his canvas. (64)

In a later part of her text the author guides her readers into an aesthetic understanding of a work of art, privileging analysis over imagination:

I suppose most people would prefer Murillo to Velasquez, because imagination is generally set on a pedestal above intellect. Murillo's imagination is like an upsoaring fountain, ever sunny and ever luminous, whilst Velasquez did not dream, but reason. He is, indeed, the most logical of painters; and what makes his works so valuable to artists and lovers of art is the quality they have in common with the masterpieces of antiquity, and which has been well called the perfection of good sense. [...] Study one of Velasquez's greatest pictures as a whole, as a creation in fact, and then set yourself to look into the

Nineteenth-Century Contests, Vol. 32, No. 1 (January 2010): pg. 47-63. DOI. This article is @ Taylor \& Francis (Routledge) and permission has been granted for this version to appear in e-Publications@Marquette. Taylor \& Francis (Routledge) does not grant permission for this article to be further copied/distributed or hosted elsewhere without the express permission from Taylor \& Francis (Routledge). 
manner of it, how much remains still to marvel and to admire. [...] Take, for instance, his colouring [...]. (66-67)

For female travelers, recognizing Velázquez as an intellectual artist was also a gesture of protest against the popular view that women's artistic experience was limited to the realm of feeling. Hence, women visitors praise Velázquez's "manly" authority, self-contained and inapprehensible by emotions. Kate Field expresses her predilection for Velázquez in such gendered terms: "Painting more honest, more manly, cannot be conceived. I'd rather have one Velázquez than dozen Murillos, for there is a virility, a scorn for nonsense and sentimentality, a respect for reality, however unlovely, that brace the soul to renew its fight for truth" (133).

Although art education opened the realm of museums to British and American men and women and provided them with analytical tools and a suitable language for describing the experience, after crossing the threshold of a foreign gallery they used to forget that their understanding of art was not innate. Thus, they tend to lose interest in analyzing artistic "schools" and developed the liking for masterpieces. By the same token, they began to hide their emotions, demonstrate the knowledge of art techniques that was only available to connoisseurs, and used art for self-cultivation. However, a set of attitudes which men expressed for the purposes of presenting themselves as quasi-aristocrats, had a different meaning for women, who posed as experts in order to protect their right to a full-fledged artistic experience and expression.

\section{A Hybrid Prado}

Serving the selected few coming from other nations was a principal function of the Prado under the Ancien Régime, and one can easily document its popularity among the transnational aristocracy prior to nationalization. The museum's cosmopolitan appeal was rooted in the idea of "virtual representation" of the nations by their elites communicating directly with one another, and this is why early literature about the Prado, including its catalogues, was addressed to both foreign and domestic audiences. What merits closer investigation, however, is the extent to which foreigners' opinions continued to have an impact on the museum when it became national and began to draw and permission has been granted for this version to appear in e-Publications@Marquette. Taylor \& Francis (Routledge) does not grant permission for this article to be further copied/distributed or hosted elsewhere without the express permission from Taylor \& Francis (Routledge). 
domestic crowds. From the preceding sections of this article one can infer that international visitors were more likely to support the museum's elitist status than to provide Spaniards with positive models of democratic museum-going.

For an institution like the Prado which maintained its links with Royalty and aristocrats for most of the nineteenth century, its popularity among foreigners could easily justify its anachronistic display mode and its narrow social appeal. At the same time, we have also seen that, in spite of their highbrow content, the travelers' writings reflected the democratization of museum-going and the rise of tourism industry. From this point of view, the enthusiastic tone of the visitors' accounts secured for the Prado a paradoxical reputation of an institution that was as popular as it was exclusive. As this final part of the article will demonstrate, the travelers' opinions played a key role in the ongoing public discussion about whether the Prado was to maintain its reputation of a "collection of masterpieces" and thus remain faithful to its aristocratic origins, or whether, on the contrary, it had to conform to the democratizing trend of putting national schools of art on display.

\section{Foreigners and the Debate about the Prado}

Since travelers' accounts imitated the conversation of educated art lovers, the authorities of the Prado-a museum deeply rooted in the culture of the cosmopolitan elites-continued to treat the foreigners' opinions as decisive even at the time when the audiences which the museum attracted were becoming less and less refined. Thus, when in the mid-1840s Richard Ford criticized the disorganization of the museum and the poor restoration of its paintings (vol. 2, 682), Pedro de Madrazo, the director's son and the author of the Catalogue, was so alarmed that he devoted eight out of ten pages of the prologue to refuting Ford's impressions (Madrazo 1850: iii-x). But Madrazo had missed the point: Ford's guidebook was not addressed to cosmopolitan aristocrats, but rather to the fast growing number of middle-class travelers attracted to what Scottish artist David Wilkie had called the "Timbuctoo of art" (quoted in Ford vol. II, 683). ${ }^{5}$ For these travelers, the lacunae and disorganization in the collection were a big part of its appeal. They made the Prado one of

Nineteenth-Century Contests, Vol. 32, No. 1 (January 2010): pg. 47-63. DOI. This article is @ Taylor \& Francis (Routledge) and permission has been granted for this version to appear in e-Publications@Marquette. Taylor \& Francis (Routledge) does not grant permission for this article to be further copied/distributed or hosted elsewhere without the express permission from Taylor \& Francis (Routledge). 
the few old-style collections of masterpieces at a time when other museums were presenting their displays in a uniform and rationalistic manner. This is why English-speaking foreigners insisted on calling the Prado "Museo Real" long after nationalization.

Since travelers' opinions were rooted in the democratic tradition of museum-going and, simultaneously, pretended to be elitist, they could serve either side of the debate about the Prado as a national museum. Outside of the narrow group of the museum authorities, liberal Spanish writers thought that foreigners, versed in the positivist discourse of art history, would be most likely to support progressive demands for its complete reorganization. Introducing the Prado in his 1876 Guía de Madrid, Ángel Fernández de los Ríos referenced the opinions of some unnamed "foreigners" in order to explain to his compatriots the importance of the museum for reconstructing the history of art and the need to transfer the ownership of art away from the Royal courts and the Church:

Foreigners who don't have too deep of a knowledge of our past get astonished at how a nation so rich in first-class artists entered our century having as its only museum the dark passages and mysterious rooms of Royal palaces and country residencies and the retablos of her temples, where [...] remained forever cornered, like diamonds framed in mud, wooden plates of great interest for the history of art and paintings on canvas which the whole world now admires. (486)

At the same time, foreign visitors' selective attention to paintings on display helped the authorities who were interested in safeguarding the Prado as a collection of masterpieces. When the museum was nationalized, liberal Spanish writers started to insist that, although it "amassed in abundant amounts treasures that are causing well-founded jealousy among foreigners, it could only be called a warehouse, rather than a museum, of art" (Tubino 1872: 506). The tendency to privilege the canon of the "Spanish school" while dismissing its minor artists and its less glamorous periods, in particular, provoked the most energetic attacks on the part of liberal Spanish critics. For Francisco María Tubino, showcasing masterpieces was evidence of the museum's outdated role-that of serving as "one of the many tools that the monarchy used to impress and captivate the spirits and imaginations of the crowds" (507). For a national museum, showcasing masterpieces was less important than illustrating

Nineteenth-Century Contests, Vol. 32, No. 1 (January 2010): pg. 47-63. DOI. This article is @ Taylor \& Francis (Routledge) and permission has been granted for this version to appear in e-Publications@Marquette. Taylor \& Francis (Routledge) does not grant permission for this article to be further copied/distributed or hosted elsewhere without the express permission from Taylor \& Francis (Routledge). 
the history of art: "We constantly hear talk of or praise for the Divine Morales, the mystical Murillo, the energetic Zurbarán or the always under-celebrated Diego Velázquez, but very rarely if ever does one come across meditations on art as an idea, as an activity, as a series of facts and manifestations" (512-13). A year later, Ceferino Araujo Sánchez, another liberal critic, went even further by declaring that the museum directors' persistent efforts to improve the conditions under which Velázquez's paintings were exhibited represented "a miserable preoccupation when the interests of art are called in question" (1873: 480). If the highest achievements of Spanish art and the gems of the Royal collection continued to be the authorities' only priority, then the Prado had to keep its earlier name of a Royal Museum, "Museo del Rey, as it is known abroad," the critic concluded, pointing at the connection between the museum's continuing elitism and its international reputation $(1875,11)$.

\section{The Foreigners' Example}

Given the delayed formation of museum spectatorship in Spain, what role if any did foreign visitors play? Some sources suggest that the Spanish liberal public, male and female, found themselves attracted by an attention to art that was virtually unknown in their own milieu. Thus, in his short story, "Ordeals," Leopoldo Alas (Clarín) described a strange Spanish couple, whom everyone took for foreigners because of their interest in art: "They spoke to each other a lot, discussing seriously what they were seeing and hearing, forgetful of the world around them, thinking about art alone, unaware of the fact that everywhere their outlandish aspect was causing surprise, not untouched by inconspicuous ridicule" (1896, digital edition). Among Spanish social groups, feminists were the ones who appreciated most the example of museum travel given by British female writers. Carmen de Burgos, an early twentieth-century feminist and journalist, found the example of British women particularly useful for her aging compatriots who would normally be removed from public eyes once they lost their reproductive functions: "In old age I want to be like these English ladies who travel continuously. See new landscapes, museums; listen to new scores .... Tour all countries... old age is only terrible for old Spanish women who lock themselves by the fireplace,

Nineteenth-Century Contests, Vol. 32, No. 1 (January 2010): pg. 47-63. DOI. This article is @ Taylor \& Francis (Routledge) and permission has been granted for this version to appear in e-Publications@Marquette. Taylor \& Francis (Routledge) does not grant permission for this article to be further copied/distributed or hosted elsewhere without the express permission from Taylor \& Francis (Routledge). 
gaining weight, praying the rosary and taking pectorals. This is why they are so obsessed with staying young...." (267).

Other sources point at the fact that, although foreign travelers did not remain unnoticed 'by the Spanish liberal public, the communication between these two groups, potentially so fruitful, was all but nonexistent. Foreign museum-goers were busy staging their own self-cultivation and posing in front of the paintings as upper-class connoisseurs. Meanwhile, the majority of Spaniards used their visits for social mingling with representatives of other classes and, especially, members of the opposite sex. Examining both domestic and Anglo-American sources therefore leaves us with a paradoxical picture of foreigners scrupulous in their attention to art yet oblivious of their surroundings and unaware of the fact that they, too, were being observed. Most often, female foreigners, immersed in the contemplation of art, became the objects of not-so-disinterested observation for Spanish men. Thus, in one of his interviews the writer Francisco Ayala suggested that, in the early years of the twentieth century, acquiring an "English girlfriend" was considered a customary result of visiting the Prado museum for middle-class Spaniards (Hiriart). ${ }^{6}$

A curious example of how two paradigms of museum-going-the foreigners' connoisseurship and the locals' leisurely mingling-crossed within the walls of the Prado can be found in Susan Hale's A Family Flight through Spain (1883). As an episode of this book suggests, American travelers studying art were not completely oblivious of the local visitors with whom they shared the museum space. Thus, on their apparently frequent visits to the Prado, Hale and her female companions would always run into a Spanish man, who remained in the same room with them. In clear contrast with their own role of art lovers who spent long hours wandering "in the long cool galleries, catalogue in hand" or studying Patinir and Rembrandt (284), Hale calls the man "Amateur, because he was always in the gallery, to fill up his time, apparently, looking at the pictures, but with more animation at the visitors" (289). He "raised the hat as they passed," obviously trying to establish contact with Hale's party, but received no reaction. Yet his impression on these American travelers must have been strong, as his lithographed portrait carrying such typified traits of a and permission has been granted for this version to appear in e-Publications@Marquette. Taylor \& Francis (Routledge) does not grant permission for this article to be further copied/distributed or hosted elsewhere without the express permission from Taylor \& Francis (Routledge). 
Latin Lover as thick mustache, long nose, and stylish outfit, appears in the book's illustrated edition. The engraved "Amateur" carried a stick, something that the visitors of the Prado were prohibited from doing.

Thus, while the authorities of the Prado continued to give high importance to the foreigners' opinions and while their liberal critics unmasked the bond between the growing touristic popularity of the museum and the deficiencies in the museum's display and social appeal, Spanish museum-goers contemplated the travelers with sympathy, jealousy, or lust. Very rarely, however, did they receive an understanding glance in return.

The strange portrait of a Spanish visitor spotted at the Prado remains a happy exception in the notes about the Prado left by British and American travelers. As we have seen, although the reputation of the museum depended heavily on the impression that it left among such travelers, my sources do not suggest that there was much if any dialogue among local and foreign visitors. True, middle-class foreigners were much better trained in analyzing art than their Spanish counterparts. Yet, having crossed the border, they proceeded to use the experience for defining their taste as an innate intuition or as a fruit of personal self-cultivation in the presence of chef-d-oeuvres. As a result, although their behavior provided positive models for Spanish visitors, their writings helped to legitimize the anachronistic nature of the Prado as a Royal collection of masterpieces. Unsurprisingly, the catalogue of the Prado published after its nationalization, yet proclaiming that there could be no better way of hanging the paintings than the one adopted by the Royal museum's directors, was reported to receive the highest praise in London's Atheneum and other foreign journals (Tubino 1872: 520).

As a result, toward the end of the century the foreigners' accounts began receiving unflattering comments from democraticallyminded Spanish writers. Thus, in an annotated bibliography completed in 1897 Manuel Bartolomé de Cossío, the leader of Spain's arteducational reform, dismissed a number of travel writings coming from Britain and the United States. Henry O'Shea, the author of several books on art travel, found in Cossío a particularly critical reader: Cossío described his Popular Guide to the Louvre as an "outdated and permission has been granted for this version to appear in e-Publications@Marquette. Taylor \& Francis (Routledge) does not grant permission for this article to be further copied/distributed or hosted elsewhere without the express permission from Taylor \& Francis (Routledge). 
assessment of paintings with quotes from Gautier," and dismissed his Guide to Spain for being "even worse than Ford's" (Archivo de la Real Academia de la Historia, Fondo Cossío file 71-1361-2). For progressive Spanish writers and educators, true love of art would require caring less about the titans like Murillo or Velázquez and paying more attention to the bulk of works comprising the national "school." Amidst this miscommunication between foreign and domestic visitors, British and American women offered the most encouraging examples to their Spanish counterparts. On either sides of the border, cultural travel and travel writing were seen as an escape from the socially-sanctioned domestic and reproductive functions imposed on women.

In the final recount, however, the Prado did not change its display and continued to bet on its international reputation until well into the twentieth century. Meanwhile, middle-class Spaniards received no assistance from the museum authorities and would have been left to their own devices, had it not been for pioneer educators like Cossío, who did not work for the museum but who were organizing regular guided tours for schoolchildren and the general public, male and female, since the $1870 \mathrm{~s}$. Whose perceptions, then, were more prominent in the museum's history? As we have seen, in the nineteenth century the Prado heavily relied on its international circulation to secure its domestic importance, while it was receiving criticism from the educated Spanish public. Thus, in its transformation from a Royal cosmopolitan site to a national museum, the Prado never stopped incorporating the foreigners' opinions into its institutionalized history. Returning to Urry's coinage, mentioned at the beginning of the article, we can now see the Prado as a "hybrid" place whose foundations were set by nineteenth-century Anglo-American cultural travelers.

\section{Notes}

[1] Since much of what the travelers write about the museum reveals their familiarity with other texts, such as Richard Ford's Handbook for Travellers in Spain and Readers at Home (1865), Sir William Sterling Maxwell's Annals of the Artists of Spain (1848), or, later on, Charles Ricketts' The Prado and its Masterpieces (1903), in 
what follows I will focus on the passages that express the writers' self-positioning, rather than provide information about the Prado.

[2] Excellent examples of how one can analyze the impact of foreign consumption and tourism on the constructions of local, regional, and national identities are found in the collected volume Tourism, Ethnicity, and the State in Asian and Pacific Societies, ed. Michel Picard and Robert E. Wood (1997).

[3] Gadamer describes "aesthetical consciousness" as an imperative of "rising to the universal, distancing from the particularity of immediate acceptance or rejection, respecting what does not correspond to one's own expectation or preferences" (73).

[4] All translations are mine.

[5] In his response to Madrazo in the 1855 (Third) Edition, Ford quoted the 1853 proceedings of the Select Parliamentary Committee reviewing restorative techniques at the Prado (vol II, 684).

[6] When asked whether he remembered anything interesting from his early visits to the Prado, Ayala replied that his own experience deviated from this rule: "I used to spend there lots and lots of hours, but I don't remember anything in particular that would stay out as an anecdote. I found no English girlfriend there at that time" (Hiriart).

\section{Works Cited}

Archivo del Museo Nacional del Prado. Libros de Visita.

Archivo de la Real Academia de la Historia. Documentos ILE. Fondo Manuel Bartolomé de Cossío.

Afinoguénova, Eugenia. "Middle-Class Spectatorship and the

Nationalization of the Prado Museum in Madrid, 1868-1900", in

The National Museum, ed. Peter Aronsson, Arne Bugge

Amundsen, and Simon J. Knell. London: Routledge, 2010

(forthcoming).

Alas (Clarín), Leopoldo. "Ordalías", in Cuentos morales. Madrid: La

España Editorial, 1896 (digital edition, Alicante: Biblioteca

Virtual Miguel de Cervantes, 2007).

Araujo Sánchez, Ceferino. "El Museo de Madrid, la Academia de San

Fernando y el nuevo catálogo del Sr. D. Pedro de Madrazo",

Revista de España, XXXI (28 de abril de 1873): 472-91. 
Bennett, Tony. The Birth of the Museum. History, Theory, Politics. London: Routledge, 1995.

- - . (ed.). Museums and Citizenship: A Resource Book. Memoirs of the Queensland Museum. Vol. 39, part 1. Queensland: Queensland Museum, 1996.

Betham Edwards, Matilda. Through Spain to the Sahara. London: Hurst and Blackett, 1868.

Bourdieu, Pierre. Distinction. A Social Critique of the Judgement of Taste. Translated by Richard Nice. Cambridge, Mass.: Harvard UP, 1984 (French edition:1979).

Buzard, James. The Beaten Track. European Tourism, Literature, and the Ways to 'Culture', 1800-1918. Oxford: Clarendon Press/Oxford UP, 1993.

- - . "The Grand Tour and After (1660-1840)", in Cambridge Companion to Travel Writing, ed. Peter Hulme and Tim Youngs. Cambridge: Cambridge UP, 2002, 37-52.

Clifford, James. Routes. Travel and Translation in the Late Twentieth Century. Cambridge, Mass.: Harvard UP, 1997.

Conlin, Jonathan. The Nation's Mantelpiece: A History of the National Gallery. London: Pallas Athene, 2007.

Cossío, Manuel Bartolomé de. "Sobre la reforma de las universidades inglesas", Boletín de la Institución Libre de Enseñanza II (1878): 165-67.

- - - "Sobre la enseñanza estética en Inglaterra", Boletín de la Institución Libre de Enseñanza XI, 1887, 321-22.

- - - "Más sobre la educación estética en Inglaterra", Boletín de la Institución Libre de Enseñanza XI, 1887, 353-54.

Day, Henry. From the Pyrenees to the Pillars of Hercules. Observations on Spain, Its History and Its People. New York: G. P. Putnam's Sons, 1883.

De Burgos, Carmen (Colombine). "El veneno del arte", in La flor de la playa y otras novelas cortas, ed. Concepción Núñez Rey. Madrid: Castalia, 1989.

De Diego Otero, Estrella. La mujer y la pintura en la España del Siglo XIX: Mujeres pintoras en Madrid, 1868-1910. Madrid: Universidad Complutenese, 1987.

De los Ríos, Ángel. Guía de Madrid. Manual del madrileño y del forastero. Madrid: Imprenta de Aribau y Compañía, 1876.

Elwes, Alfred. Through Spain by Rail in 1872. London: E. Wilson, 1873.

Nineteenth-Century Contests, Vol. 32, No. 1 (January 2010): pg. 47-63. DOI. This article is (C Taylor \& Francis (Routledge) and permission has been granted for this version to appear in e-Publications@Marquette. Taylor \& Francis (Routledge) does not grant permission for this article to be further copied/distributed or hosted elsewhere without the express permission from Taylor \& Francis (Routledge). 
Field, Kate. Ten Days in Spain (September, 1873). Boston and New York: Houghton, Mifflin, and Co., 1892.

Ford, Richard. Handbook for Travellers in Spain, and Readers at Home. Describing the Country and Cities, the Natives and their Manners; the Antiquities, Religion, Legends, Fine Arts, Literature, Sports and Gastronomy: with notices on Spanish History. 2 vols. London: John Murray, 1845.

Gadamer, Hans-Georg. Truth and Method. Second revised edition. Transl. revised by Joel Weinsheimer and Donald G. Marshall. London, New York: Continuum Books, 2004.

Géal, Pierre. La naissance des musées d'Art en Espagne (XVIIe - XIXe siècles). Madrid: Casa Velázquez, 2005.

Grant Dexter, Edwin G. A History of Education in the United States. New York: Macmillan, 1904.

Gregory, James. "Lady Mount Temple and her Friendship with Constance Wilde", The Oscholars III (31:12), November/December 2006 (electronic publication).

Hale, Susan. A Family Flight through Spain. Boston: D. Lothrop and Co, 1883.

Harvey, Annie Jane. Cositas Españolas, or Every Day Life in Spain. London: Hurst and Blackett, 1875.

Hay, John. Castilian Days. Boston and New York: Houghton, Mifflin, and Co., 1907. (First ed. 1871).

Hiriart, Rosario. Conversaciones con Francisco de Ayala. (Digital edition based on Madrid: Espasa-Calpe, 1982)

Hoock, Holger. "Reforming Culture: National Art Institutions in the Age of Reform", in Rethinking the Age of Reform. Britain 1780-1850, ed. Arthur Burns and Joanna Innes. Cambridge: Cambridge UP 2003.

Madrazo, Pedro de. Catálogo de los cuadros del Real Museo de Pintura y Escultura de S. M, Madrid: Aguado, 1850.

Mandler, Peter. "Art in a Cool Climate: The Cultural Policy of the British State in European Context, c. 1780 to c. 1850", in Unity and Diversity in European Culture, c. 1800, ed. Tim Blanning and Hagen Schulze. Oxford: Oxford UP, 2006.

Merimée, Prosper. "Les grands maîtres du Musée de Madrid", L'Artiste, 1 (March 1831): 73-75.

O'Shea, Henry. A Guide to Spain. London: Longmans, Green and Co, 1865. 
- - - Les Musées du Louvre, guide populaire. Paris: E. Dentu, 1892.

Picard, Michel, and Robert E. Wood (eds.). Tourism, Ethnicity, and the State in Asian and Pacific Societies. Honolulu: $U$ of Hawaii $P$, 1997.

Prior, Nick. Museums and Modernity. Art Galleries and the Making of Modern Culture. Oxford: Berg, 2002.

Rees, Joan. Matilda Betham-Edwards: Novelist, Travel writer and Francophile. Hastings: Hastings Press. 2006.

Ricketts, Charles S. The Prado and its Masterpieces. Westminster: Archibald Constable and Co., 1903.

Sempere y Miguel, Salvador. "Aplicación del arte a la industria: las escuelas para la enseñanza del dibujo", Revista de España XXID (28 de noviembre de 1872): 239-64.

- - - "Aplicación del arte a la industria: las escuelas inglesas para la enseñanza del dibujo", Revista de España XXX (13 de enero de 1873): 103-14; (13 de febrero): 385-98. XXXI (28 de marzo): 222-35; (28 de abril): 514-32. XXXII (28 de mayo): 215-25. Scharnhorst, Gary. Kate Field: The Many Lives of a Nineteenth-Century American Journalist. Syracuse: Syracuse U P, 2008.

Tollemache, Marguerite. Spanish Towns and Spanish Pictures: a Guide to the Galleries of Spain. London: J.T. Hayes: 1870.

-- - Spanish Mystics: A Sequel to Many Voices. London: Paul, Trench \& Co., 1886.

Tubino, Francisco María. "El Museo del Prado, la Academia de Bellas Artes y el Catálogo del Señor Madrazo", Revista de España XXDC (28 de diciembre de 1872): 506-30.

--_. "La reforma artística", Revista de España XXXI (28 de marzo de 1873): 170-85.

Urry, John. "How Societies Remember the Past", in Theorizing Museums, ed. Sharon Macdonald and Gordon Fyfe. Oxford: Blackwell, 1996.

Whitehead, Christopher. The Public Art Museum in Nineteenth-Century Britain. Aldershot: Ashgate, 2005. and permission has been granted for this version to appear in e-Publications@Marquette. Taylor \& Francis (Routledge) does not grant permission for this article to be further copied/distributed or hosted elsewhere without the express permission from Taylor \& Francis (Routledge). 